\title{
QUESTIONING THE BEHAVIORAL ASSUMPTION UNDERLYING WIGMOREAN ABSOLUTISM IN THE LAW OF EVIDENTIARY PRIVILEGES
}

\author{
Edward J. Imwinkelried
}

Has certainty perhaps been bought at the price of justice?

From society's perspective, the rules governing privileged communications such as those between a client and his or her attorney are arguably the most important doctrines in evidence law. Most evidentiary doctrines relate to the court's institutional concerns. By way of example, the best evidence and hearsay rules are largely designed to enhance the reliability of the evidence on which the trier of fact bases his or her findings. ${ }^{2}$ The primary impact of these rules is on the in-court behavior of witnesses, attorneys, and judges.

In sharp contrast, privilege doctrines concern "extrinsic policy"3; they affect the out-of-court behavior of actors such as clients and patients. Thus, "the rule governing privileges" can be justifiably viewed as the most significant evidentiary doctrine. ${ }^{4}$ During the 1973 congressional hearings on the then proposed Federal Rules of Evidence, former Supreme Court Justice

* Distinguished Professor of Law, University ofCalifornia, Davis; former chair, Evidence Section, American Association of Law Schools; author, The New Wigmore: Evidentiary Privileges (2002) (2 vols.). Based in part on Chapter 5 of The New Wigmore: Evidentiary Privilegges. Reprinted with permission. The author wishes to express his gratitude to Dean Paul O'Connor and the Faculty of Law, University College Dublin who hosted the author's 2003 sabbatical and enabled the author to conduct the research reflected in Part IV of this article.

1. H.L. Ho, Note, Legal Professional Privilege After Death of Client, 115 L.Q. REv. 27, 30 (1999) (commenting on the United States Supreme Court's decision in Swidler \& Berlin v. United States, 524 U.S. 399 (1998)).

2. See generally Dale A. Nance, The Best Evidence Principle, 73 Iowa L. Rev. 227 (1988) (arguing that common law exclusionary rules such as hearsay and best evidence implement a best evidence principle, giving parties an incentive to provide the trier of fact with the most reliable basis for factual findings).

3. 8 John Henry Wigmore, Evidence in Trials at Common Law $§ 2175$ (McNaughton rev. 1961).

4. Edward Copeland et al., Revisiting the Codification of Privileges under the Federal Rules of Evidence, 55 ReC. Ass'N BAR OF CITY OF N.Y. 143, 150-51 (Jan./Feb. 2000). 
Arthur Goldberg distinguished privilege doctrine from other evidentiary rules. In his words,

[privilege law] is the concern of the public at large. [Privileges] involve the relations between husband and wife. As the Supreme Court suggested in Griswold v. Connecticut [381 U.S. 479 (1965)] the marital privilege constitutes the basis of the family relation and antedates even the adoption of our Constitution. They involve the relations between lawyer and client, a privilege that long antedates the adoption of our Constitution. They relate to the fundamental rights of citizens. ${ }^{5}$

During the House deliberations on the proposed Rules, one representative remarked that "unlike most evidentiary rules, privileges protect interpersonal relationships outside of the courtroom." Since the adoption of the Federal Rules of Evidence, the Supreme Court has handed down more decisions relating to privilege law than any other part of the Federal Rules of Evidence. ${ }^{7}$

Of all the commentators on privilege law, the late Dean John Henry Wigmore is easily the most important. Justice Frankfurter asserted that the Dean's treatise on evidence is "without any rivalry the greatest treatise on law in the English tongue." evidence law, Professor Edmund Morgan of Harvard, stated: "Not only is this ... by far [] the best treatise on the Law of Evidence, it is also the best work ever produced on any comparable division of Anglo-American law." "In most areas of evidence law, though, the influence of the treatise has waned. For instance, Wigmore's treatment of expert opinion is badly outdated. Wigmore's volume devoted to opinion testimony predates both the advent of DNA typing and the enactment of the Federal Rules of Evidence. ${ }^{10}$

However, in some evidentiary areas the treatise still exercises great authority. ${ }^{11}$ Notably, privilege law is the field where the treatise continues to enjoy the greatest sway. The Advisory Committee that drafted the Federal Rules of Evidence frequently cited Wigmore's treatise in the official Notes to

5. Testimony of Hon. Arthur J. Goldberg, Rules of Evidence, Special Subcomm. on Reform ofFed. Criminal Laws, Comm. on the Judiciary, H.R. Rep., 93 Cong., 1 st Sess. 142, 143-44 (1973).

6. Comm. of the Judiciary, Federal Rules of Evidence, H.R. REP. No. 93-650, at 28 (1973).

7. Molly Rebecca Bryson, Note, Protecting Confidential Communications Between a Psychotherapist and Patient: Jaffee v. Redmond, 46 CATH. U. L. Rev. 963, 963 n.1 (1997).

8. Justice Felix Frankfurter, Address to the Harvard Law Society of Illinois (Apr. 28, 1955), quoted in Gerald T. Dunne, Book Review, 30 St. Louis U. L.J. 567, 569 (1986).

9. Edmund Morgan, Review of Wigmore's Treatise, 20 B.U. L. REv. 776, 793 (1940).

10. See Daubert v. Merrell Dow Pharmaceuticals, 509 U.S. 579 (1993); David Kaye, David Bernstein \& Jennifer Mnook in, The New Wigmore: Expert Evidence (2004).

11. William Twining, Theories of Evidence: Bentham and Wigmore 171-72 (1985) [hereinafter TWINING, THEORIES]. 
its proposed privilege provisions. ${ }^{12}$ During the discussion of those provisions in the congressional hearings on the proposed Federal Rules, witness after witness invoked the authority of Wigmore to justify his or her position. ${ }^{13}$ The courts repeatedly mention the treatise as support for their reasoning in privilege cases. ${ }^{14}$ In a late 1980 s privilege decision, the Supreme Court itself asserted that Dean Wigmore's theory has long been viewed as the rationale for privileges. ${ }^{15}$ In its two most recent privilege decisions, Jaffee v. Redmond ${ }^{16}$ in 1996 and Swidler \& Berlin v. United States ${ }^{17}$ in 1998, the Supreme Court appealed to the treatise as authority.

One of the most important tenets of Wigmore's position on privileges is that a true communications privilege ${ }^{18}$ must be "absolute" in character. Understanding the meaning of that term in this context is critical. On the one hand, Wigmore understood that at a systemic level, courts and legislatures must employ a balancing test to determine whether, as a matter of policy, to recognize a privilege for a particular social relationship such as attorney-client or psychotherapist-patient. ${ }^{19}$ Moreover, Wigmore acknowledged that the holder of a privilege ought to be allowed to waive the privilege and that the scope of a privilege could be subject to an exception stated beforehand in clear, bright-line terms. ${ }^{20}$

On the other hand, Wigmore adamantly insisted that if a privilege applied and there was no special exception to its scope, the opposing party should not be permitted to defeat the privilege by an ad hoc, case-specific showing of need for the privileged information. ${ }^{21}$ Wigmore forbade the trial judge from using a balancing test to decide whether, in a given case, the opponent's need for the privileged information outweighs the policies supporting the

12. Federal Rules of Evidence 2003-2004 Edition 235, 237, 240, 243-47, 249, 253, 255, 257 (West 2003).

13. See 1 Edward Imwinkelried, The New Wigmore: Evidentiary Privileges § 4.2.2. (2002) [hereinafter 1 ImWinkelRied, The New Wigmore].

14. 1 McCormick on Evidence $§ 72$ (John W. Strong ed., 5 th ed. 1999).

15. See United States v. Zolin, 491 U.S. 554, 563 (1989).

16. Jaffee v. Redmond, 518 U.S. 1, 9 (1996).

17. Swidler \& Berlin v. United States, 524 U.S. 399, 406 (1998).

18. Although some privileges such as attorney-client protect communications between persons standing in a privileged relationship, other privileges are topical in nature. The latter privileges such as the one for military or state secrets protect facts related to a particular topic.

19. See Deana A. Pollard, Unconscious Bias and Self-Critical Analysis: The Case for a Qualified Evidentiary Equal Employment Opportunity Privilege, 74 WASH. L. REv. 913, 998 (1999).

20. Edward J. Imwinkelried, The New Wigmore: An Essay on Rethinking the Foundation of Evidentiary Privileges, 83 B.U. L. REv. 315, 319-20 (2003).

21. Id. 
privilege. ${ }^{22}$ Wigmore's key behavioral assumption was that without the assurance of confidentiality furnished by a formal evidentiary privilege, laypersons such as potential legal clients would not consult with or confide in consultants such as attorneys. ${ }^{23}$ The Supreme Court echoed Wigmore in its 1981 opinion in Upjohn Co. v. United States. ${ }^{24}$ The Upjohn Court declared that at the very time of their interaction, the participants in confidential communications "must be able to predict with some degree of certainty whether particular discussions will be protected." 25 If the layperson cannot confidently forecast that, in the future, the law will cloak his or her revelation with a privilege, the layperson supposedly would not consult or confide. The layperson could not make such a forecast if, after the fact of the communication, a judge could override the privilege based on a showing of need. In Wigmore's mind, there ought to be relatively few privileges; but if, at a systemic level, a privilege is warranted, the privilege has to be absolute to achieve the desired behavioral effect.

The Supreme Court has not only generally adopted Dean Wigmore's approach to privilege analysis. More to the point, the Court has specifically endorsed Wigmore's insistence on absolute privileges. In Jaffee, the Court of Appeals for the Seventh Circuit had recognized a psychotherapist privilege but classified it as conditional or qualified. ${ }^{26}$ However, when the case reached the Supreme Court, the Court both recognized the privilege and categorized it as absolute in a Wigmorean sense. ${ }^{27}$ The Court did likewise in 1998 in Swidler \& Berlin. There, the lower court, the Court of Appeals for the District of Columbia, had ruled that in criminal cases, otherwise privileged communications by a deceased client may be treated as qualified. ${ }^{28}$ As in Jaffee, the Supreme Court in Swidler \& Berlin forcefully rejected the treatment of the privilege as qualified. ${ }^{29}$ The Court classified the privilege as absolute to avoid "introduc[ing] substantial uncertainty into the privilege's application." ${ }^{30}$ The Court emphasized that "[b]alancing ex post the

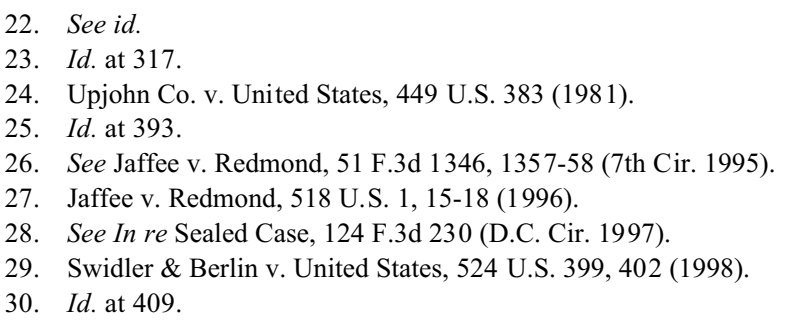


importance of the information against client interests . . . introduces" intolerable uncertainty into the privilege's application. ${ }^{31}$

Treating privileges as absolute is undeniably comforting to the members of the professions which enjoy the privileges. Further, classifying the privilege as absolute simplifies the courts' task in administering privilege rules. However, the basic question is the validity of the behavioral assumption underlying Wigmore's insistence on absolute privileges. Is it true that but for an evidentiary privilege, the average layperson standing in a confidential relationship would not consult or confide? Simply stated, that generalization is flawed. The first part of this article outlines Dean Wigmore's theory of privileges, highlighting his argument that true privileges must be absolute. The second part of the article collects empirical studies which, to say the least, call the validity of Wigmore's assumption into question. The third part of the article points out that under American constitutional law, even purportedly absolute privileges are already qualified; given the right facts creating a compelling need for privileged information, either a criminal accused or a civil litigant can surmount a privilege claim. The fourth and final part of the article turns to comparative law. That part demonstrates that many progressive legal systems classify their evidentiary privileges as qualified seemingly with little negative impact on the flourishing legal and psychotherapy professions in those countries.

As Part I explains, Wigmore's behavioral assumption enabled him to argue that the recognition of privileges comes relatively cost free to the judicial system. Wigmore reasoned that on balance, suppressing privileged information did not impair judicial fact-finding because, but for the privilege, the evidence would not have come into existence. Consequently, Wigmore could assert that the recognition of privileges caused few, if any, miscarriages of substantive justice. However, if his behavioral assumption is in error, Wigmore may have badly understated the extent to which the recognition of absolute privileges imperils the courts' ability to dispense justice. The theses of this article are that Wigmore's behavioral assumption is erroneous and that the demands of substantive justice require a reappraisal of the treatment of communications privileges as absolute. 


\section{The Rationale for Traditional Wigmorean Absolutism}

Wigmore's predecessor was Jeremy Bentham, the great eighteenth and nineteenth century English utilitarian philosopher who subscribed to the truth theory of adjudication. ${ }^{32}$ Bentham believed that the first and foremost objective of the judicial system is to accurately ascertain the truth. ${ }^{33}$ In assessing evidentiary rules, Bentham attached the utmost priority to the criterion of whether they promote rectitude of decision. ${ }^{34}$ As a general proposition, he opposed exclusionary rules which block the introduction of probative evidence. In his words, "[e]vidence is the basis of justice; exclude evidence, you exclude justice." " In particular, with the exception of the clergy-penitent privilege and the Crown privilege for state secrets, he favored the wholesale abolition of privileges. ${ }^{36}$ For example, Bentham savagely attacked the attorney-client privilege. ${ }^{37}$

For his part, Wigmore was in sympathy with Bentham's rationalist premise that the main objective in adjudication is rectitude of decision. ${ }^{38}$ However, Wigmore perceived the possibility of reconciling the objective of rectitude of decision with the recognition of privileges such as attorney-client. Wigmore attempted to effect the reconciliation in the conditions he prescribed for recognizing a communications privilege. In the most cited passage in his treatise, ${ }^{39}$ Dean Wigmore wrote:

32. See generally Barbara J. Shapiro, "Beyond Reasonable Doubt" and "Probable Cause": Historical Perspective on the Anglo-American Law of Evidence (1991) (discussing the philosophical assumptions which were dominant when Bentham wrote); TwINING, THEORIEs, supra note 11 (describing Bentham's strong commitment to the truth theory).

33. TWINING, THEORIES, supra note 11.

34. Id. at 70; William Twining, Rethinking Evidence: Exploratory Essays 72 (1994) [hereinafter TWINING, RETHINKING].

35. 1 Jeremy Bentham, Rationale of Judicial Evidence pt. III, ch. 1 (1827).

36. Twining, Theories, supra note 11, at 99; Twining, Rethinking, supra note 34, at 334. See also 6 The Works of Jeremy Bentham Published Under the Superintendence of his Executor, John Bowring 98-100, 368-69 (1962); 7 The Works of Jeremy Bentham Published Under the SuPER INTENDENCE OF HIS EXECUTOR, JOHN BOWRING 366-68, 472-86 (1962).

37. Twining, Theories, supra note 11, at 99. See Jeremy Bentham, A Treatise on Judicial EVIDENCE 197-98 (1825).

38. Twining, THEORIEs, supra note 11 , at 14-16.

39. See, e.g., Witten v. A.H. Smith \& Co., 100 F.R.D. 446, 452 (D. Md. 1984); Beth Israel Hosp. v. Dist. Ct., 683 P.2d 343, 345 (Colo. 1984); Berst v. Chipman, 653 P.2d 107, 114 (Kan. 1982); State v. Hurley, 876 S.W.2d 57, 63 (Tenn. 1993); Senear v. Daily Journal-American, 641 P.2d 1180, 1182 (Wash. 1982); MCCoRmick, supra note 14, $\S 72$, at 300 (stating that the criteria "have been widely accepted by the courts, and have largely conditioned the development of thinking about privilege"); Jack Achiezer Guggenheim\& Dr. Aaron D. Werbel, Confidentially Speaking: Why the Psychotherapist-Patient Privilege 
Looking back upon the principle of privilege, as an exception to the general liability of every person to give testimony upon all facts inquired of in a court of justice, and keeping in view that preponderance of extrinsic policy which alone can justify the recognition of any such exception ... four fundamental conditions are recognized as necessary to the establishment of a privilege against the disclosure of communications:

(1) The communications must originate in a confidence that they will not be disclosed; (2) This element of confidentiality must be essential to the full and satisfactory maintenance of the relation between the parties;

(3) The relation must be one which in the opinion of the community ought to be sedulously fostered;

(4) The injury that would inure to the relation by the disclosure of the communication must be greater than the benefit thereby gained for the correct disposal of litigation. Only if those four conditions are present should a privilege be recognized. . . . These four conditions must serve as the foundation of policy for determining all . . . privileges, whether claimed or established. ${ }^{40}$

Wigmore realized that few claimed privileges could pass the muster of these criteria; but he believed that if a privilege did so, the privilege had to be classified as absolute. ${ }^{41}$ The communicating parties stood in a relationship in which confidentiality was truly "essential," and the communication "originate[d]" because the layperson had an expectation that his or her revelation would "not be disclosed." 42 The communication would not transpire if it were not for the privilege securing that expectation.

Should Include Employee Assistance Program ("EAP”) Counselors, 68 UMKC L. REv. 29, 33 (1999); Honorable Marian Blank Horn, A Trial Judge's Perspective-Promoting Justice and Fairness While Protecting Privilege, 26 Ford ham Urb. L.J. 1429, 1439-40 (1999); Kit Kinports, The "Privilege" in the Privilege Doctrine: A Feminist Analysis of the Evidentiary Privileges for Confidential Communications, in Feminist Perspectives on Evidence 79, 82 n.22 (Mary Childs \& Louise Ellison eds., 2000) (citing In re Grand Jury, 103 F.3d 1140, 1152 (3d Cir. 1997)); Allred v. State, 554 P.2d 411, 417 (Alaska 1976); State v. Jackson, 687 A.2d 485, 487 (Conn. 1997); Steven R. Smith, Constitutional Privacy in Psychotherapy, 49 Geo. Wash. L. Rev. 1, 46 (1980).

40. Wigmore, supra note $3, \S 2285$, at 527-28.

41. J.A. Coutts, House of Lords: Evidence of Instructions to Legal Advisers, 60 J. CRIM. L. 176, 179-90 (1996) (stating that "as long as the rule is based on its present premises and is accepted as being for its present purpose, the rule must be accepted as absolute. There can be no half-way house .... As Lord Taylor CJ precisely and succinctly put it, one exception and the rule itself and the purpose it serves must at once be abandoned.").

42. WigMORE, supra note $3, \S 2285$. 


\section{A. The Benefit to Society}

Wigmore rationalized his position with classic utilitarian, cost/benefit analysis. The benefit in this utilitarian calculus was the promotion of important social relations in which confidentiality is "essential." 43

Wigmore concluded that confidentiality was inessential in most social relations even in some such as doctor-patient, which enjoy a formal privilege in many states. To begin with, he pointed out that the medical privilege applied to many communications about facts such as "asthma" and "broken ribs," which are "disclosable without shame." has an overpowering motive to provide the physician with any information that the physician requests. ${ }^{45}$ If the patient is in excruciating pain and hopes that the physician will be able to prescribe a treatment to alleviate the pain, it struck Wigmore as "ludicrous" to think that the patient needed the incentive of an evidentiary privilege to disclose information. ${ }^{46}$ Wigmore attributed the widespread recognition of the medical privilege to the successful lobbying efforts of the medical profession. ${ }^{47}$

In contrast, he concluded that confidentiality is essential in a few social relations such as that between a client and his or her lawyer. He supported his conclusion by quoting sweeping language in a number of famous English decisions on the attorney-client privilege. ${ }^{48} \mathrm{He}$ cited the language in one eighteenth century decision to the effect that if there were no privilege, "there would be an entire stop to [legal] business; nobody would trust an attorney with the state of his affairs." 49 A nineteenth century decision declared that "[d]eprived of" a privilege, "a man would not venture to consult any skillful [attorney], or would only dare to tell his counselor half his case." 50 The potential client had to be in a position to have "unbounded confidence" in an

\section{See id.}

44. Id. $\S 2380 \mathrm{a}$, at 830 .

45. $I d$.

46. $I d$.

47. Id. $\S 2380 \mathrm{a}$, at 831 .

48. Id. § 2291, at 545-47. Wigmore also quoted an article in The Law Magazine in which an anonymous author asked, "[b]ut how will a client venture to lay before his counsel a statement of all the facts of his case, if that very statement may hereafter be evidenced against him?” Id. § 2291, at 547.

49. Id. § 2291, at 545-46 (quoting Annesley v. Earl of Anglesea, 17 How. St. Tr. 1129, 1225, 1241 (Ex. 1743)).

50. Id. § 2291, at 546 (quoting Greenough v. Gaskell, 39 Eng. Rep. 618, 620 (Ch. 1833)). See also Hilary Delany \& Declan McGrath, Civil Procedure in the Superior Courts $§ 8.004$, at 232 (2001) (an Irish text). 
"absolute guarantee of confidentiality." disclosure even "in limited circumstances" in which the opponent has a critical need for the privileged communications, there would be a "chilling effect" on the potential client's willingness to confer and confide. ${ }^{52}$

The courts, including the Supreme Court, have embraced Wigmore's conclusion. According to the Connecticut Supreme Court, the abolition of the attorney-client privilege would mean "an end to all confidence between the client and attorney." ${ }^{33}$ In 1976, the year after the Federal Rules of Evidence took effect, the Supreme Court in Fisher v. United States ${ }^{54}$ asserted that the attorney-client privilege is designed to "protect[] only those disclosures - necessary to obtain informed advice - which might not have been made absent the privilege." ${ }^{55}$ In its 1996 decision in Jaffee, Justice Stevens elaborated:

[T] he likely evidentiary benefit that would result from the denial of the [psychotherapist] privilege is modest. If the privilege were rejected, confidential conversations between psychotherapists and their patients would surely be chilled .... Without a privilege, much of the desirable evidence to which litigants such as [plaintiff] seek access-for example, admissions . . . by a party - is unlikely to come into being. This unspoken "evidence" would therefore serve no greater truth-seeking function than if it had been spoken and privileged. ${ }^{56}$

The Court recurred to the same theme in Swidler \& Berlin. There, Chief Justice Rehnquist stated that "without the privilege, the client may not have made such communications in the first place."

Wigmore and the proponents of his position thus conceive absolute privileges as a necessary incentive for the average layperson contemplating a communication with a professional confidant such as an attorney. ${ }^{58}$ The assumption is that there is a causal relationship between the creation of the privilege and the occurrence of the desired behavior; but for the existence of

51. Delany \& McGrath, supra note 50, § 8.030, at 232.

52. Id. The authors cite Williams v. Quebrada Railway, Land and Copper Co., [1895] 2 Ch. 751, 754. In that case, Kekewich cautioned that the privilege "should not be in any way departed from." Williams, 2 Ch. at 754.

53. Metro. Life Ins. Co. v. Aetna Cas. \& Sur. Co., 730 A.2d 51, 60 (Conn. 1999).

54. Fisher v. United States, 425 U.S. 391 (1976).

55. Id. at 403 .

56. Jaffee v. Redmond, 518 U.S. 1, 11-12 (1996).

57. Swidler \& Berlin v. United States, 524 U.S. 399, 408 (1998).

58. 1 Imwinkelried, The New Wigmore, supra note 13, § 3.2.3, at $132 \mathrm{n} .82$ (discussing Dean Wigmore's description of his position in his treatise). 
the privilege, the typical person would supposedly be unwilling to engage in the behavior of consulting and confiding. ${ }^{59}$

\section{B. The Cost to the Legal System}

Positing Wigmore's behavioral assumption not only dictates the conclusion that there is much to be gained by classifying privileges as absolute; the same assumption also leads to the conclusion that there is little to be lost by doing so. ${ }^{60}$ As Professor Melanie Leslie has observed, "[i]n a perfect [Wigmorean] world, the privilege would shield no evidence. Privilege generates the communication that the privilege protects. Eliminate the privilege, and the communication disappears. . . [T] he privilege would protect only ... statements that would not otherwise have been made." ${ }^{\prime 61}$ Even in the imperfect world he lived in, Wigmore believed that if the courts rigorously applied his criteria, in the vast majority of cases the privileges would suppress only statements which would not have been uttered but for the assurance of confidentiality they furnish. ${ }^{62}$ Wigmore thought that there would be a "wash" 33 - the justice system would not be in a worse net position when the trial judge enforced the privilege to exclude evidence because in most instances, absent the privilege the evidence would never have come into existence. ${ }^{64}$

This belief has many adherents. In commenting on the privilege for spousal communications, one of the leading modern jurists, Judge Richard Posner has stated:

Even if the benefits of marital privilege are slight, the costs in valuable evidence foregone also may be slight .... . [F] or if the privilege were abolished, and this were widely known, spouses would be much less likely to make damaging admissions to each other;

59. 3 Jack B. Weinstein \& Margaret A. Berger, Weinstein's Federal Evidence para. 504.03[4][a], at 504-10 to 11 (John M. McLaughlin ed., 2d ed. 2003).

60. 1 ImWinkelried, The New Wigmore, supra note 13, § 3.2.3., at 133-38.

61. Melanie B. Leslie, The Costs of Confidentiality and the Purpose of Privilege, 2000 Wis. L. REv. $31,31(2000)$.

62. 1 Imwinkelried, The New Wigmore, supra note 13, § 3.2.3., at 133-38.

63. Pollard, supra note 19, at 999.

64. See Vincent C. Alexander, The Corporate Attorney-Client Privilege: A Study of the Participants, 63 St. John's L. Rev. 191, 216, 231 (1989). See also Weinstein \& Berger, supra note 59, $\S 504.03[4][\mathrm{a}]$, at 504-10 to 11 (stating that "[t]he recognition of the privilege has little cost to the judicial system, because . . . if the privilege were not recognized, many of the confidential disclosures would never be made"). 
and so abolition would not create a cornucopia of valuable evidence. . . [A]bolishing marital privilege might cause such admissions to quite dry up . .. ${ }^{65}$

National legal organizations have advanced a similar argument in defense of an expansive attorney-client privilege. For example, in an official publication, the American Bar Association asserted that the recognition of the privilege does "not caus[e] any substantial obstruction to the investigation of facts." Similarly, the American Law Institute has stated that "perhaps the evidence excluded by the privilege would not have come into existence save for the privilege. ${ }^{967}$

In addition, most courts have adopted Wigmore's belief. In 1998, a federal district court declared that the recognition of even an absolute privilege would "result[] in little evidentiary detriment where the evidence lost would simply never come into being if the privilege did not exist." Supreme Court has repeatedly made it clear that it subscribes to this belief. As previously stated, in 1976 in Fisher, the Court indicated that attorneyclient communications "might not have been made absent the privilege." Two decades later in Jaffee, Justice Stevens stated that without the benefit of a privilege, "much of the desirable" psychotherapist-patient communication that could qualify as "admissions . . . by a party . . . is unlikely to come into being." 70 Two years later in Swidler \& Berlin the Chief Justice explained that in the case of the enforcement of the attorney-client privilege, "the loss of evidence is more apparent than real." $" 11$ The Chief Justice conceded that there is a seeming loss of relevant evidence when a trial judge enforces a privilege, but he added that "without the privilege, the client may not have made such communications in the first place." $" 72$

If one accepts the premise that in these relations the average layperson would not consult or confide absent a privilege, Wigmore's cost/benefit analysis is sound. The analysis not only justifies classifying communications privileges as absolute; it virtually necessitates treating privileges in that

65. Richard A. Posner, An Economic Approach to the Law of Evidence, 51 StAn. L. Rev. 1477, 1531 (1999).

66. Wigmore, supra note 3, $\S 2299$, at 567 (quoting the American Bar Association Committee on the Improvement of the Law of Evidence).

67. Restatement (Third) of the Law Governing Lawyers $\S 68 \mathrm{cmt}$ c c (2000).

68. Folb v. Motion Picture Indus. Pension \& Health Plans, 16 F. Supp. 2d 1164, 1178 (C.D. Cal. 1998).

69. Fisher v. United States, 425 U.S. 391, 403 (1976).

70. Jaffee v. Redmond, 518 U.S. 1, 11-12 (1996).

71. Swidler \& Berlin v. United States, 524 U.S. 399, 408 (1998).

72. Id. 
fashion. When an assurance of confidentiality is truly "essential," these useful social interactions will not occur absent a privilege. The assumption is that the layperson would refrain from consulting unless, at the time of the communication, the layperson can confidently predict that a court will later apply the privilege to suppress testimony about the communication. The prediction becomes impossible if, at a later point in time, a trial judge could override the privilege simply because the opponent made a persuasive showing of need for the privileged information. As Wigmore saw, the only way to secure the layperson's expectation of confidentiality was to recognize privileges that could be defeated only by waiver and exceptions announced beforehand - in other words, privileges that are absolute in the technical sense.

\section{The Empirical Studies of the Behavioral Assumption Underlying Wigmorean AbSOLUtism}

Wigmore's behavioral assumption is the establishment view in the American law of privileges. ${ }^{73}$ Moreover, as Wigmore himself correctly noted, the assumption is plausible. ${ }^{74}$ However, it can be a grave mistake to equate the plausible with the proven. In truth, the assumption is unsubstantiated. ${ }^{75}$ There have been several empirical studies of the impact of the evidentiary privileges on the willingness of clients and patients to confide in professional consultants, and those studies do not bear out Wigmore's generalization. ${ }^{76}$

\section{A. The Attorney-Client Studies}

The attorney-client privilege is the privilege which the Supreme Court dealt with in Swidler \& Berlin. ${ }^{77}$ At early common law, the attorney-client privilege applied only when the client consulted the attorney during

73. Richard Lempert, The Economic Analysis of Evidence Law: Common Sense on Stilts, 87 VA. L. Rev. 1619, 1688 (2001).

74. Wigmore, supra note $3, \S 2291$, at 549 .

75. Lempert, supra note 73 , at 1690 (stating that assumptions substantiating the marital privilege are "ungrounded").

76. See generally Edward Imwinkelried, The Rivalry Between Truth and Privilege: The Weakness of the Supreme Court's Instrumental Reasoning in Jaffee v. Redmond, 518 U.S. 1 (1996), 49 HastingS L.J. 969 (1998) (discussing the psychotherapy studies); see also Richard C. Wydick, The Attorney-Client Privilege: Does It Really Have Life Everlasting?, 87 Ky. L.J. 1165, 1173-74 (1998-99) (discussing the attorney-client studies).

77. Swidler \& Berlin v. United States, 524 U.S. 399 (1998). 
litigation. ${ }^{78}$ However, the contemporary view gives the privilege broader scope; by virtue of that view, the privilege attaches whenever the client seeks legal advice. ${ }^{79}$ As Professor Paschal observed during the congressional deliberations over the proposed Federal Rules of Evidence, many attorneyclient consultations relate to "pre-litigation conduct." ${ }^{\prime 80}$ Hence, the privilege can come into play when the client consults a transactional attorney to structure a business arrangement with a lifelong friend-years before it ever occurs to the client that there might be a falling out with the other businessperson and ensuing litigation. The common experience of transactional attorneys is that their clients are blooming optimists about the success of the business arrangements they contemplate entering. The client may have little concern about the chance of subsequent litigation and the prospect of compelled judicial disclosure of confidences during the litigation. The client's "focus tends to be on the 'here and now' rather than on disclosure at some indefinite future time." $" 1$

In light of the applicability of the modern attorney-client privilege to prelitigation consultations, the findings in the following empirical studies of the attorney-client privilege are perhaps not surprising.

In 1962, Yale Law Journal published the results of one of the first studies of this subject. ${ }^{82}$ The researchers received completed questionnaires from 108 laypersons. ${ }^{83}$ The response to question number eight is noteworthy. In their responses to that question, one-third of the laypersons indicated that they assumed that the judge could order an attorney to reveal client confidences. ${ }^{84}$ In other words, many were willing to consult an attorney despite their erroneous assumption that a judge had the power to override the privilege ad hoc - strongly suggesting that they would still use an attorney's services if the privilege were actually classified as qualified rather than absolute. Commenting on the study, Professor Fred Zacharias stated that cumulatively, the study's findings "support the notion that confidentiality rules have some

78. See 1 Imwinkelried, The New Wigmore, supra note $13, \S 6.11 .1$.

79. See id.

80. Federal Rules of Evidence: Hearing on H.R. 5463 Before the Senate Comm. on the Judiciary, 93d Cong., 89 (1974).

81. Edward J. Imwinkelried, Court Ducks Larger Privilege Issues Yet Again, NAT'L L.J., July 20, 1998 , at A22.

82. See Comment, Functional Overlap Between the Lawyer and Other Professionals: Its Implications for the Privileged Communications Doctrine, 71 YALE L.J. 1226 (1962) [hereinafter Functional].

83. Id. at 1227 n.6.

84. Id. at 1262 . 
impact on the way clients use attorneys. But they also cast doubt on whether the effect is as substantial as proponents of confidentiality presume." ${ }^{155}$ As he read the data, "a substantial majority of laypersons would continue to use lawyers even if secrecy were limited."

In part because the Yale research called into question the received orthodoxy, Professor Zacharias felt impelled to conduct a further study in the 1980's. He surveyed laypersons in Tompkins County, New York. ${ }^{87} \mathrm{He}$ interviewed 105 laypersons,$^{88}$ roughly the same number of lay respondents in the earlier Yale study. ${ }^{89}$ Approximately half of the laypersons indicated that they would withhold some information from attorneys if there were no legal rules shielding the confidentiality of their communications with attorneys. ${ }^{90}$ However, the respondents' other answers appeared to indicate that they would be willing to consult and confide if there were a limited privilege protecting their communications. ${ }^{91}$ For example, in nine hypothetical cases, forty to sixty percent of the respondents stated that they assumed that their attorneys would have discretion to disclose the communication without their permission. ${ }^{92}$ The laypersons' responses prompted Professor Zacharias to conclude that "strict" confidentiality may be unnecessary. ${ }^{93}$

Professor Vincent Alexander conducted another study during the 1980's as part of the course of study for his Doctor of Science of Law degree. ${ }^{94}$ Although Professor Zacharias focused on natural person clients, Professor Alexander studied the corporate attorney-client privilege. He interviewed corporate executives headquartered in Manhattan. He considered New York City "an ideal site," since at the time "Manhattan contained the largest concentration in the United States of corporate headquarters with internal legal departments on the premises. ${ }^{95}$ The executives' answers indicated that in their contacts with in-house counsel, they relied more heavily on their trust in the individual attorney rather than on any assumption about the state of

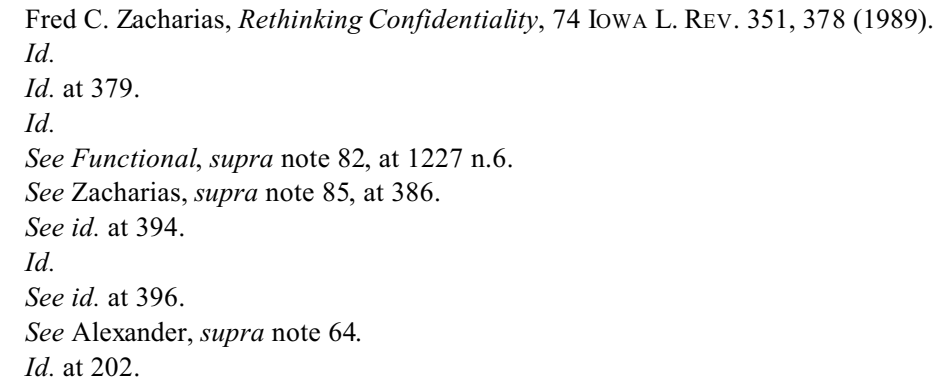


evidence law. ${ }^{96}$ The key was whether in their past dealings the attorney had created rapport ${ }^{97}$ and proved worthy of the executive's trust. If the privilege were abolished or curtailed, the executives would likely continue to consult these counsel..$^{98}$ The modification of the privilege would probably have little or no effect on the frequency of consultation. ${ }^{99}$ For that matter, most oral consultations would continue to be as candid as in the past. ${ }^{100}$ The real impact would be on written communication between the executives and counsel; they would put fewer things in writing and be more circumspect in written communication. ${ }^{01}$

After reviewing his data, Professor Alexander found that in the corporate setting, the operation of the privilege is overinclusive; it applies to many communications that would be made even if there were no privilege. ${ }^{102}$ The data strongly suggested that in the corporate context, the scope of the privilege is unduly broad. ${ }^{103}$ The data raised the question of whether any privilege should attach to communications between business executives and their inhouse counsel. ${ }^{104}$ The data appeared to undermine the assumption that an absolute privilege is necessary. ${ }^{105}$ Professor Alexander concluded that it would work little damage to the free flow of corporate attorney-client communications if the privilege were converted into a qualified one, capable of being overridden in exceptional cases of compelling need. ${ }^{106}$

\section{B. The Psychotherapist-Patient Studies}

As in the case of the attorney-client privilege, there has been a small number of studies of the psychotherapy privilege, the privilege the Supreme Court addressed in Jaffee. ${ }^{107}$ As in the case of the attorney-client privilege, the available data seems at odds with the assumption that the existence of an absolute privilege is necessary to promote psychotherapist-patient

\footnotetext{
96. See id. at 248.

97. See id. at 277.

98. Id. at $225,263$.

99. Id. at 248-49.

100. Id. at 264 .

101. Id. at $264,371,374$.

102. $I d$. at 267 .

103. Id. at 200 .

104. Id. at 279 .

105. Id. at 368,384

106. Id. at $201,381,415$.

107. Jaffee v. Redmond, 518 U.S. 1 (1996).
} 
communications. ${ }^{108}$ In his dissent in Jaffee, Justice Scalia asked rhetorically "how come psychotherapy got to be a thriving practice before the 'psychotherapist privilege' was invented?"'109 After reviewing the history of psychotherapy, Professor Ralph Slovenko, one of the most respected commentators on law and psychiatry, noted that "we cannot blind ourselves to the fact that the practice of psychotherapy has grown, indeed flourished, in an environment of a non-absolute privilege." ${ }^{110}$ In the past, the recognition of an absolute privilege was inessential to the growth of the field; and the empirical studies conducted to date indicate that the future maintenance of psychotherapy does not require such a privilege.

The Miller-Thelen study is illustrative. ${ }^{111}$ Those researchers acknowledged that there is data indicating that the "level of confidentiality has little effect on client behavior." "12 Classifying the privilege as absolute rather than qualified provides an additional increment of legal protection for the confidentiality of psychotherapy, but that additional increment may have little impact on the conduct of patients.

Donald Schmid headed another group of researchers who investigated the topic. ${ }^{113}$ In that study, in response to a general query, sixty-seven percent of the patients stated that they would be upset by a revelation of their confidences by hospital staff members without their permission. ${ }^{114}$ However, only thirty-three percent indicated that they would be concerned by a release

108. Suzanne B. McNicol, Law of Privilege 349 (1992) (the studies persuaded this Australian textwriter that the existence of a formal evidentiary privilege "is of consequence to few patients and in few cases").

109. Jaffee, 518 U.S. at 24 (Scalia, J., dissenting).

110. Ralph Slovenko, The Psychotherapist-Patient Privilege, 57 Am. J. Psychoanalysis 63, 68 (1997) (quoting In re Lifschutz, 467 P.2d 557, 564 (Cal. 1970)). Before the Supreme Court's decision in Jaffee v. Redmond, 518 U.S. 1 (1996), several lower federal courts had recognized a psychotherapistprivilege. In re Doe, 964 F.2d 1325, 1328 (2d Cir. 1992); Cesar v. Mountanos, 542 F.2d 1064, 1067 n.9 (9th Cir. 1976). There was a discernible trend to characterize the privilege as conditional rather than absolute. Christopher B. Mueller \& Laird C. Kirkpatrick, Modern Evidence: Doctrine and Practice $\S 5.37$, at 626 (1995) (citing In re Doe, 964 F.2d at 1328 and Dixon v. City of Lawton, 898 F.2d 1443, 1450-51 (10th Cir. 1990)); 25 Charles Alan Wright \& Kenneth W. Graham, Jr., Federal Practice And Procedure: Evidence $\S 5522$, at 137 (1989) (“[T] he largest group of cases seem to be groping toward a qualified privilege ....") (citing Jennings v. D.H.L. Airlines, 101 F.R.D. 549 (N.D. Ill. 1984); United States v. Witt, 542 F. Supp. 696 (S.D.N.Y.)); Melissa L. Nelken, The Limits of Privilege: The Developing Scope of Federal Psychotherapist-Patient Privilege Law, 20 Rev. Litig. 1, 5 (2000).

111. David J. Miller \& Mark H. Thelen, Knowledge and Beliefs About Confidentiality in Psychotherapy, 17 Prof. Psychol.: Res. \& Prac. 15 (1986).

112. Id.

113. Donald Schmid et al., Confidentiality in Psychiatry: A Study of the Patient's View, 34 Hosp. \& COMmunity Psychiatry 353 (1983).

114. $I d$. at 354 . 
of information to a court. ${ }^{115}$ That percentage is substantial enough to demonstrate that there is a measure of truth in Wigmore's assumption but it nonetheless falls short of validating the generalization that the typical patient would refrain from consulting or confiding absent a privilege. The respondents were much more concerned about out-of-court disclosures to employers and insurers. ${ }^{116}$

Another research team included Applebaum, Kapen, Walters, Lidz, and Roth. ${ }^{117}$ They questioned inpatients as well as outpatients. ${ }^{118}$ In both groups, only a minority of respondents stated that they would have any "[n]egative reaction[]" to a therapist's unauthorized disclosure of confidential information to courts. ${ }^{119}$ As in the Schmid study, the researchers discovered that patients were far more concerned about out-of-court disclosure to employers. ${ }^{120}$ The researchers reported that "the outpatients we interviewed did not appear concerned about absolute confidentiality." conclude that patients would "seek and participate in psychiatric treatment even in [the] absence" of confidentiality protection. ${ }^{122}$

Daniel Shuman was the lead investigator in a Canadian-American study. ${ }^{123}$ In the Canadian phase of the study, "[o]nly seventeen percent" of the respondents replied that they "rely most strongly on privilege" law in deciding whether to make disclosures to their therapists; instead, they relied primarily on their assessment of the therapist's sense of professional ethics. ${ }^{124}$ The researchers found no "statistically significant difference" between the attitudes of patients residing in provinces without a privilege and those living in provinces recognizing a privilege. ${ }^{125}$ In the American stage of the study, eighty-six percent of the respondents stated that they relied on the therapist's

115. $I d$.

116. See Rhonda McMillion, Calendar Countdown: Congress Facing Self-Imposed Deadline to Pass Measures for Protection of Medical Record Privacy, 85 A.B.A. J., Aug. 1999, at 97.

117. Paul S. Applebaum, MD et al., Confidentiality: An Empirical Test of the Utilitarian Perspective, 12 Bull. Am. AcAd. Psychiatry \& L. 109 (1984).

118. Id. at 113 .

119. $I d$.

120. $I d$.

121. Id. at 115 .

122. Id. at 114 .

123. Daniel W. Shuman et al., The Privilege Study (Part III): Psychotherapist-Patient Communications in Canada, 9 InT'L J.L. \& Psychiatry 393 (1986) [hereinafter Shuman, Part III]; Daniel W. Shuman \& Myron S. Weiner, The Privilege Study: An Empirical Examination of the PsychotherapistPatient Privilege, 60 N.C. L. Rev. 893 (1982).

124. Shuman, Part III, supra note 123, at 407.

125. Id. at 411 . 
professional ethics - "not privilege" law - in deciding whether to consult and confide. ${ }^{126}$ Although some American patients reported withholding information from therapists, "[ $\mathrm{t}]$ his withholding seemed unrelated to the presence or absence of [an evidentiary] privilege, and most of these patients indicated that a privilege would not have resulted in fuller disclosure." 127 The researchers concluded that "people do not look to [evidence] law for guidance in their decision to enter into therapy or make disclosures in therapy." ${ }^{\prime 28}$ In the researchers' words, "the evidence for the proposition that a psychotherapist-patient privilege is necessary for effective psychotherapy is highly questionable." 129

It must be conceded that the number of empirical studies is quite small. Moreover, the studies inquire into what did or would have motivated laypersons to engage in certain types of conduct, and "[s]ocial psychology studies indicate that people are often unable to say what really motivated them. Thus, empirical studies relying on self-reporting about whether the existence of a privilege affected the privilege-holders' behavior are inherently indeterminate." ${ }^{\prime 30}$ For that matter, the studies support the conclusions that absent a privilege, a significant minority of persons would be more guarded in their written communications and that a small minority might be altogether deterred from consulting.

However, none of the studies lends any solid support to Wigmore's generalization that without the assurance of confidentiality furnished by an evidentiary privilege, the average or typical layperson would not consult or confide. At least in these studies, the lay respondents were not as concerned about judicially compelled disclosure of confidences as Wigmore hypothesized. The world does not appear to revolve around the courtroom to the extent that Wigmore assumed. If it does not, the case for absolute evidentiary privileges is markedly weaker than Wigmore made it out to be.

\section{The American Constitutional Doctrines Rendering Even Purportedly Absolute Privileges Qualified}

Those who claim that communications privileges must remain absolute to maintain the vitality of relationships such as attorney-client and 
psychotherapist-patient overlook the fact that, to a degree, in the United States even purportedly absolute privileges are already qualified. The privileges have been rendered qualified to an extent because criminal accused and civil litigants have a constitutional right to surmount the privilege in order to introduce critical, demonstrably reliable evidence. The American legal and psychotherapy professions are somehow surviving even though they no longer enjoy truly absolute privileges.

\section{A. The Criminal Accused}

The starting point in this constitutional line of authority is the Supreme Court's 1967 decision in Washington v. Texas. ${ }^{131}$ In that case, the Court dealt with the constitutionality of two Texas statutes providing that an accused could not call as a defense witness any person charged or previously convicted as a principal, accomplice, or accessory in the same crime. ${ }^{132}$ The statutes rendered such persons incompetent as defense witnesses. ${ }^{133}$ The accused, Jackie Washington, was charged with murder in a shooting. ${ }^{134}$ Washington attempted to call Charles Fuller as a witness. ${ }^{135}$ The defense made an offer of proof that Fuller would testify Washington had tried to prevent Fuller from shooting. ${ }^{136}$ The rub for the defense was that Fuller had already been convicted of murder in the same shooting incident. ${ }^{137}$ Citing the two Texas statutes, the prosecutor objected to Fuller's testimony; and the trial judge sustained the objection. ${ }^{138}$ Without the benefit of Fuller's exculpatory testimony, Washington was convicted. ${ }^{139}$ The Supreme Court reversed the conviction. ${ }^{140}$ In doing so, the Court issued two significant rulings.

First, writing for the majority, Chief Justice Warren held that the compulsory process guarantee of the Sixth Amendment is so fundamental that it is incorporated in the due process provision of the Fourteenth

\footnotetext{
131. Washington v. Texas, 388 U.S. 14 (1967).

132. Id. at $14-16$.

133. Id. at $16-17$.

134. See id. at 15.

135. See id. at 16-17.

136. See id.

137. Id.

138. Id.

139. Id. at 15 .

140. Id. at 17.
} 
Amendment. ${ }^{141}$ The guarantee was therefore enforceable directly against states such as Texas.

Second, and even more importantly for our present purposes, the Court held that the Texas statute violated the guarantee. ${ }^{142}$ Texas had argued that it had not denied Washington compulsory process; it allowed him to subpoena Fuller as a witness. ${ }^{143}$ Texas's argument struck the Chief Justice as a reductio ad absurdum. ${ }^{144}$ Chief Justice Warren asserted, "[t]he Framers of the Constitution did not intend to commit the futile act of giving to a defendant the right to secure the attendance of witnesses whose testimony he has no right to use." 145 Warren stated flatly that a criminal accused "has the right to present his own witnesses to establish a defense." ${ }^{146}$ Elaborating, the Chief Justice explained that the express compulsory process guarantee gives a criminal accused an implied "right to put on the stand a witness who [is] physically and mentally capable of testifying to events that he [has] personally observed, and whose testimony would have been relevant and material to the defense." 147

Washington left many questions unanswered. One pivotal question was whether the new implied right applies only to broad, incompetency rules that completely barred persons from appearing as defense witnesses. Suppose that the jurisdiction's evidentiary rules permitted the person to take the witness stand but restricted the content of his or her testimony. Assume, for example, that the jurisdiction's hearsay rule prevented a defense witness from testifying to critical exculpatory facts. Could the defense invoke Washington to override the rule?

The Supreme Court reached that question in 1973 in Chambers $v$. Mississippi. ${ }^{148}$ One of the alleged constitutional errors in that case was the trial judge's exclusion of vital, exculpatory hearsay evidence. ${ }^{149}$ Like Washington, Chambers was charged with murder, in this case, the shooting of a police officer. ${ }^{150}$ The defense theory was that another person named Gable

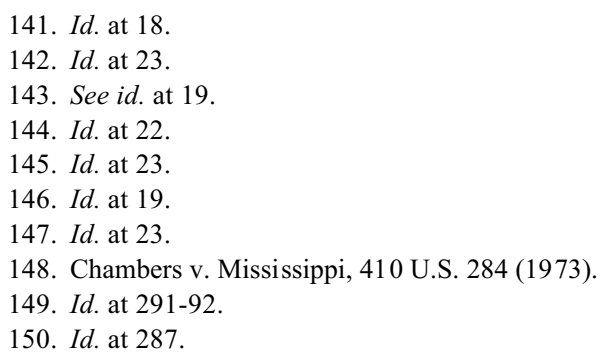


McDonald was the real shooter. ${ }^{151}$ The defense attempted to introduce the testimony of three of McDonald's acquaintances that he, McDonald, had told them that he had shot the police officer. ${ }^{152}$ The trial judge excluded the testimony for the stated reason that Mississippi followed the traditional common law doctrine that the declaration against interest hearsay exception includes only statements disserving proprietary and pecuniary interest, not penal interest. ${ }^{153}$ In reversing, the Supreme Court powerfully reaffirmed Washington ${ }^{154}$ Citing Washington, Justice Powell found that the trial judge's ruling violated the accused's right "to present witnesses in his own defense." 155 The Court thus refused to apply the implied right only to competence rules altogether barring a witness's testimony; ${ }^{156}$ the Court extended the reach of the right to evidentiary rules that have the more limited effect of preventing a witness from giving particular testimony.

The only remaining issue was whether ultimately, the courts would take the next step and employ the right to strike down privileges in addition to rules, such as the hearsay doctrine, primarily designed to exclude untrustworthy evidence. Two other Supreme Court decisions made that step predictable.

One decision was a much earlier case, Roviaro v. United States, handed down in $1957 .{ }^{157}$ In that case, the Court recognized the common law governmental privilege for an informer's identity. ${ }^{158}$ The Court justified the privilege on extrinsic social policy grounds, that is, encouraging private citizens to report crimes to the police. ${ }^{159}$ However, Justice Burton made it clear that the privilege is conditional:

A . . . limitation on the applicability of the privilege arises from the fundamental requirements of fairness. Where the disclosure of an informer's identity, or of the contents of his communication, is relevant and helpful to the defense of an accused, or is essential to a fair determination of a cause, the privilege must give way. ${ }^{160}$

151. Id. at 289 .

152. $I d$.

153. Id. at $290-92$.

154. Id. at 302 .

155. $I d$.

156. See id.

157. Roviaro v. United States, 353 U.S. 53 (1957).

158. See id. at 59.

159. See id.

160. Id. at 61-62. 
Thus, when there was a grave risk that the mechanical enforcement of the privilege would cause a miscarriage of justice, the privilege had to yield. Admittedly, in Roviaro, the Court stopped short of announcing a constitutional rule. Rather, the Court reached the result in Roviaro by exercising its supervisory power over lower federal courts. ${ }^{161}$ However, the constitutional overtones of the decision were patent, replete with references to "fundamental requirements of fairness." 162 For that reason, the lower courts have come to view the doctrine as of constitutional dimension. ${ }^{163}$

The second decision is Davis v. Alaska. ${ }^{164}$ That decision was published in 1974, the year after Chambers. In Davis, although the Court did not rely on the compulsory process guarantee, the Court invoked the cognate Sixth Amendment right, confrontation. ${ }^{165}$ There, the star prosecution witness was Richard Green. ${ }^{166}$ To show Green's bias, the defense counsel attempted to cross-examine the witness about his juvenile court probationary status. ${ }^{167}$ The trial judge had granted a protective order, barring the defense counsel from eliciting that fact. ${ }^{168}$ The trial judge's order was based on a state statute and court rule makingjuvenile court proceedings confidential. ${ }^{169}$ Functionally, the statute and court rule created absolute privileges; they barred the admission of logically relevant evidence to foster an extrinsic social policy, the "rehabilitative goals of the juvenile correctional procedures." acknowledged that the pursuit of that goal is a legitimate government policy. ${ }^{171}$ Nevertheless, the Court held that the Confrontation Clause entitled the accused to present the excluded evidence to the jury; the accused's need

161. See McCray v. Illinois, 386 U.S. 300, 311 (1967) (characterizing Roviaro as "formulating evidentiary rules for federal criminal trials").

162. Roviaro, 353 U.S. at 60.

163. United States v. Bailey, 834 F.2d 218, 223 (1st Cir. 1987).

164. Davis v. Alaska, 415 U.S. 308 (1974).

165. Id. at 315 .

166. Id. at 310 .

167. The defense counsel made it clear that he was not proffering the testimony to impeach Green's general credibility. $I d$. at 311 . Instead, the defense counsel identified a two-fold inference of bias. See id. First, Green was still on probation for his juvenile offense. Id. Hence, he might have "acted out of fear or concern of possible jeopardy to his probation." Id. Green could have "fear[ed] . . possible probation revocation" if he did not please the police and prosecutor. Id. Second, Green's juvenile offense was a burglary, the same offense Davis was charged with in the instant case. Consequently, Green might have wanted "to shift suspicion away from himself . ..." Id.

168. Id. at 311 .

169. Id. at $311 \mathrm{nn} .1-2$.

170. Id. at 319 .

171. Id. 
for the evidence outweighed the extrinsic policies underlying the statute and court rule. ${ }^{172}$

The lessons from these Supreme Court decisions have not been lost on the lower courts. There is a large body of case law invoking the Sixth Amendment to permit an accused to surmount absolute privileges which threatened to prevent the accused from introducing critical, demonstrably reliable evidence. For example, the courts have ruled that the attorneyclient $^{173}$ and psychotherapist-patient ${ }^{174}$ privileges yield when the accused establishes an exceptionally strong need for the privileged information. In similar fact situations, in which the accused had an acute need for the information, the courts have overridden the marriage counselor-client, ${ }^{175}$ physician-patient, ${ }^{176}$ rape counselor, ${ }^{177}$ and spousal ${ }^{178}$ privileges. In some cases the privilege overridden was legislative in character $^{179}$ while in other cases the privilege was a creature of case law. The common denominator was that in all these cases, the privilege purported or had been construed to be absolute. Nevertheless, in an extreme case in which the accused desperately needed the privileged information to establish his or her innocence, the implied Sixth Amendment right trumped the privilege.

172. See id. at 319-21.

173. Edward J. Imwinkelried \& Norman M. Garland, Exculpatory Evidence: The Accused's Constitutional Right to Introduce Favorable Evidence $\S 10-5$ a (2d ed. 1996) [hereinafter ImWinkelried \& Garland, EXCUlPatory] (discussing Salem v. North Carolina, 374 F. Supp. 1281 (W.D.N.C. 1974); Vela v. Superior Court, 255 Cal. Rptr. 921 (1989); and State v. Pearson, 22 A.T.L.A. L. Rep. 409 (Ohio Ct. App. 1979)).

174. Id. § 10-5d (collecting cases); Norman M. Garland \& Edward J. Imwinkelried, Exculpatory Evidence: The Accused's Constitutional Right to Introduce Favorable Evidence $\S 10-5 d$, at 79-80 (2d ed. Supp. 2003) (discussing United States v. Alperin, 128 F. Supp. 2d 1251 (N.D. Cal. 2001); United States v. Hansen, 955 F. Supp. 1225 (D. Mont. 1997)).

175. ImWinkelRiEd \& GARLAND, EXCUlPatory, supra note 173, § 10-5b, at 305-06 (discussing State v. Roma, 363 A.2d 923 (N.J. Super. Ct. Law Div. 1976)).

176. Id. § 10-5c (discussing State v. Hembd, 232 N.W.2d 872, 874-76 (Minn. 1976); State v. Trammel, 435 N.W.2d 197 (Neb. 1989); State v. Parillo, 480 A.2d 1349 (R.I. 1984)).

177. Id. § 10-5e, at 315-16 (discussing In re Robert H., 509 A.2d 475 (Conn. 1986), Commonwealth v. Two Juveniles, 491 N.E.2d 234 (Mass. 1986); Advisory Opinion to the House of Representatives, 469 A.2d 1161 (R.I. 1983)).

178. Id. § 10-5f (discussing Salazar v. State, 559 P.2d 66 (Alaska 1976); Rubio v. Superior Court, 249 Cal. Rptr. 419 (Cal. Ct. App. 1988); People v. Foskey, 529 N.E.2d 1158 (Ill. App. Ct. 1988)).

179. E.g., State v. Roma, 363 A.2d 923 (N.J. Super. Ct. Law Div. 1976) (analyzing New Jersey's statutory marriage counselor privilege) 


\section{B. Civil Litigants}

All the cases discussed in subpart A invoke the Sixth Amendment. By its terms, that amendment applies only "in . . criminal prosecutions . . .". 180 Until recently, it had not been suggested, much less held, that civil litigants enjoy a parallel constitutional right to surmount privileges which would block their access to critical information.

\section{The Argument from Policy}

However, in principle, a strong case can be made that a parallel right exists under the Fifth and Fourteenth Amendment guarantees of procedural due process. ${ }^{181}$ By virtue of those guarantees, the government may not deprive citizens of property interests without affording them due process of law. Civil judicial proceedings unquestionably constitute government action. ${ }^{182}$ Moreover, civil judgments can result in the deprivation of property rights. For purposes of due process analysis, the concept of property includes myriad forms of property, including a legal cause of action. ${ }^{183}$ The issue is whether the right to present evidence is one of the procedures constitutionally "due" citizens in civil actions.

The justices of the Supreme Court differ over the proper approach to determining the procedures that are "due" or mandated constitutionally in civil cases. ${ }^{184}$ The majority of the justices subscribe to an instrumental conception of the procedural due process guarante $\mathrm{e}^{185}$ — as a means to an end. The end is enhancing the accuracy of fact-finding in civil proceedings. ${ }^{186}$ As former

180. U.S. Const. amend. VI.

181. See generally Edward J. Imwinkelried, The Case for Recognizing a New Constitutional Entitlement: The Right to Present Favorable Evidence in Civil Cases, 1990 UtaH L. Rev. 1 (1990) (suggesting, for the first time, the existence of this right in civil cases and attempting to construct a case under the due process clause).

182. See John E. NowaK \& Ronald D. Rotunda, Constitutional Law § 13.7 (5th ed. 1995); John Nowak et al., Treatise on Constitutional Law: Substance and Procedure $\S 17.9$, at 42 (Supp. 1989) ("[T] he Supreme Court's focus ... often centers on questions of fairness and reliability of the fact finding process, concerns which are the heart of due process analysis.”); Cardoso v. Reno, 127 F. Supp. 2d 106, 116 (D. Conn. 2001) ("Procedural due process protections are designed to help ensure accuracy in the truth finding process ....").

183. Opdyke Inv. Co. v. City of Detroit, 883 F.2d 1265, 1274 (6th Cir. 1989).

184. Laurence H. Tribe, American Constitutional Law $\S 10-7$, at 663-77 (2d ed. 1988).

185. Id. $\S 10-13$, at 714 .

186. See id. $\S 10-13$, at 718 . 
Chief Justice Burger once wrote, the mission of the procedural due process guarantee "is to minimize the risk of erroneous decisions." ${ }^{187}$ Through its legislatures and courts, society makes policy choices embodied in substantive rules of law. Affording participants in civil cases the incidents of procedural due process helps ensure that those choices are enforced accurately. ${ }^{188}$

A minority of the justices, though, advocate an intrinsic conception of procedural due process. ${ }^{189}$ In their view, the active participation of citizens in civil proceedings is more than a mere means to the end of accurate factfinding; participation itself has intrinsic value. ${ }^{190}$ In a democratic society, citizens should participate actively in civil proceedings that impact their interests. Citizen participation affirms an individual's dignity as a human being $^{191}$ and enables individuals personally to assert their rights. ${ }^{192}$ Participation allows the individual to exercise some control over the government proceeding - a control that was prized under the individualistic philosophy dominant in eighteenth and nineteenth century England. ${ }^{193}$

Under either approach, the right to present evidence ought to be held to be an essential element of procedural due process in civil actions. Under the instrumental approach, the essential question is whether the proposed procedure will materially advance the accuracy of fact-finding. Recognition of the right to present evidence would certainly do so. The opportunity to present evidence is the most basic means available to a party to prevent the trier of fact from committing factual errors. If a party fears the trier will make an erroneous finding, the party presents evidence contradicting that finding. Further, one party's right to present evidence creates a disincentive for the other party to offer misleading evidence. The latter party realizes that even if the judge admits the misleading evidence, the former party can introduce contradictory evidence that not only will specifically rebut the misleading evidence, but generally lower the latter party's credibility in the trier's mind.

The right to present evidence should also be deemed an essential element of procedural due process under the intrinsic approach. It is an axiom of

187. Greenholtz v. Inmates of Neb. Penal \& Corr. Complex, 442 U.S. 1, 13 (1979).

188. See TRIBE, supra note $184, \S 10-12$, at 711 .

189. Id. $\S 10-7$, at 675 .

190. See id. $\$ 10-7$, at 666 .

191. See id.

192. See Stephan Landsman, Readings on Adver sarial Justice: The American Approach to ADJUDICATION 34 (1988) (stating that "[a]dversary theory holds that if a party is intimately involved in the adjudicatory process and feels that he has been given a fair opportunity to present his case, he is likely to accept the results whether favorable or not").

193. See id. at 20 . 
procedural due process that as a person possessed of human dignity, a citizen has a right to be heard ${ }^{194}$ before a governmental tribunal deprives that person of a property right. That right is meaningless unless, in the first instance, the citizen has a right to speak actively to the tribunal. The indignity of inquisitorial procedure is that the citizen must stand by passively and silently while a tribunal makes a decision determining the citizen's fate or fortune. At the most basic level, adjudicatory proceedings conducted by judicial tribunals are evidentiary hearings. ${ }^{195}$ If the citizen has any meaningful right to speak actively to the tribunal and participate in the tribunal's hearing, that right must subsume the opportunity to present evidence. There are many cases holding that, with rare exceptions, ${ }^{196}$ citizens in administrative hearings have a due process right to present evidence. ${ }^{197}$ If respect for human dignity requires recognition of a constitutional right to present evidence in informal administrative settings, a fortiori, citizens must be granted the same right in civil judicial proceedings.

\section{The Argument from Precedent}

Although the theoretical case for recognizing the constitutional right in civil suits is strong, until recently there was no precedent squarely endorsing the theory. However, there are now cases holding that there is a constitutional right to present evidence in civil actions and, more to the point, a right that can be invoked to override absolute privileges.

The seminal holding is the Kansas Supreme Court's 1998 decision in Adams v. St. Francis Regional Medical Center. ${ }^{198}$ There, the plaintiffs alleged that the negligence of the defendant hospital's employees caused their daughter's death. ${ }^{199}$ They contended that a nurse negligently failed to

194. Sniadach v. Family Fin. Corp., 395 U.S. 337, 342 (1969); see Gideon v. Wainwright, 372 U.S. 335, 344-45 (1963).

195. Wheeler v. Montgomery, 397 U.S. 280, 281-82 (1970)

196. Goss v. Lopez, 419 U.S. 565 (1975) (holding that although due process requires that students facing suspension be accorded some type of hearing, the nature of the hearing may be modified to accommodate competing interests); Wolff v. McDonnell, 418 U.S. 539, 566 (1974) (holding that an inmate in a disciplinary hearing may present evidence in his defense so long as the presentation will not be "unduly hazardous to institutional safety or correctional goals").

197. See Goldberg v. Kelly, 397 U.S. 254, 269 (1970); Henry J. Friendly, Some Kind of Hearing, 123 U. PA. L. Rev. 1267, 1282 n.80 (1975) (discussing due process right to present evidence in prison and school disciplinary proceedings).

198. Adams v. St. Francis Reg'1 Med. Ctr., 955 P.2d 1169 (Kan. 1998).

199. Id. at 1171. 
recognize the seriousness of their daughter's condition and neglected to alert a physician to her need for immediate attention. ${ }^{200}$

The incident was investigated by the Kansas State Board of Nursing. ${ }^{201}$ The hospital prepared some documents and submitted them to the board. ${ }^{202}$ The board generated other documents, and still other documents reflected investigations of earlier, similar alleged acts of incompetence by the nurse. ${ }^{203}$ During discovery, the defendant sought protective orders to preclude the plaintiffs from inspecting the documents. ${ }^{204}$ The lower court granted the orders because it concluded that the documents were protected by the Kansas statutory medical peer review privilege. ${ }^{205}$ The plaintiffs filed a motion challenging the constitutionality of the statute as applied, but the lower court denied the motion. ${ }^{206}$

Eventually, the plaintiffs appealed to the Kansas Supreme Court. ${ }^{207}$ The court agreed with the trial judge that several of the documents were cloaked by the statutory privilege. ${ }^{208}$ The court concluded that five key documents sought by the plaintiffs "are protected by a literal reading of the peer review privilege set out in K.S.A. 1997 Supp. 69-4915 (b) and (d) . . .."209

However, the court then addressed the question of whether, as applied, the statutory privilege was constitutional. The court found a constitutional violation. ${ }^{210}$ The court cited a number of federal and state precedents suggesting the existence of a constitutional right to present evidence in civil cases. ${ }^{211}$ The court then declared that at least when "[t] he information sought" goes "to the "heart' of the case," "the substantive interest in preserving the confidentiality of information 'must give way to assure that all the facts will be available for a fair determination of the issues ...."'212

In 2000, the Mississippi Supreme Court issued a decision similarly recognizing the constitutional right in Baptist Memorial Hospital-Union

200. $I d$.

201. Id. at 1172 .

202. Id. at 1171-72.

203. $I d$.

204. Id. at 1172 .

205. Id.

206. Id. at 1173 .

207. See id. at 1171.

208. Id. at 1183 .

209. Id.

210. Id. at $1186-88$.

211. Id. at $1184-86$.

212. Id. at 1186 . 
County v. Johnson. ${ }^{213}$ In Johnson, the plaintiff mother gave birth to her child at the defendant hospital. ${ }^{214}$ A nurse on the defendant's staff negligently delivered the child to another woman for nursing. ${ }^{215}$ The latter women breastfed the child. ${ }^{216}$ When the plaintiff subsequently discovered the mixup, she sued the hospital for negligence. ${ }^{217}$ In order to determine whether the breastfeeding might imperil her child's health, she sought to discover the other woman's identity and medical records. ${ }^{218}$ The hospital objected, claiming the state statutory physician-patient privilege on behalf of the unidentified patient. $^{219}$

On the preliminary issues in the case, the hospital prevailed. For instance, the court ruled that the hospital could assert the privilege on the unidentified patient's behalf. ${ }^{220}$ Furthermore, the court concluded that the state medical privilege was so broad that it applied to both the patient's identity and the information contained in her medical records. ${ }^{221}$

However, the court next pointed to an earlier line of criminal cases holding that the "public policy" implicated in "investigat[ing] and solving ... crimes" sometimes outweighs the privacy rights underpinning evidentiary privileges. ${ }^{222}$ Those cases announced that when information is "crucial" in a prosecution, it cannot be suppressed even "under the guise of the physicianpatient privilege." ${ }^{\prime 23}$ The defendant hospital urged the court to limit the line of authority to criminal cases. But, the court refused to do so. The court reasoned that just as there is a "compelling" public interest in accurately determining the guilt or innocence of accused, the public interests at stake in a civil case can be weighty enough to override an absolute privilege. ${ }^{224}$ The court remarked that "[t]his especially holds true when the health and life of another are potentially at stake." 225 The court thus made it clear that given the

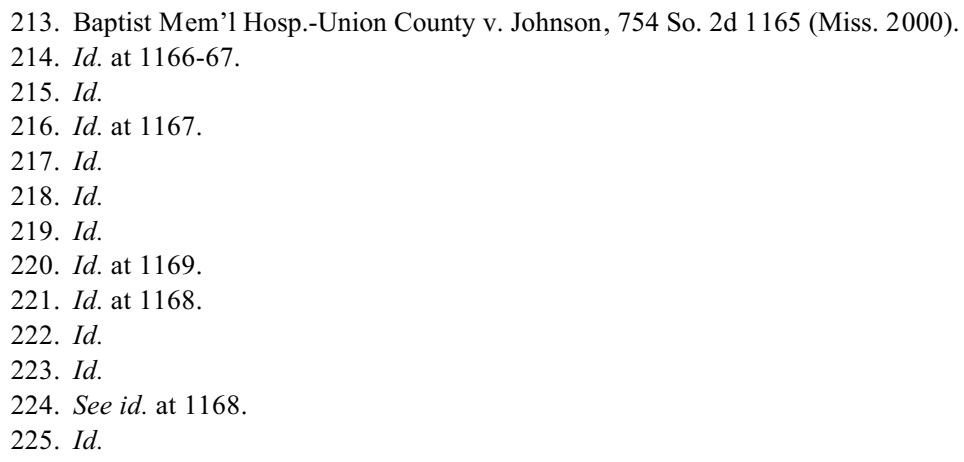


right facts, a purportedly absolute privilege may have to yield in either a civil or a criminal case. ${ }^{226}$

\section{The Experience of Other Countries with Qualified Privileges}

Part II of this article reviewed the empirical studies calling into question the behavioral assumption underlying Dean Wigmore's absolutism. Part III of the article demonstrated that in a constitutional sense, even purportedly absolute privileges in the United States are already qualified. However, it might be countered that the constitutional doctrines discussed in Part III do little to undermine the average layperson's expectation of confidentiality that Wigmore presumed. In the criminal arena, the courts have invoked the implied Sixth Amendment right only in extreme fact situations. Chambers is a case in point. ${ }^{27}$ In that case, there was considerable evidence that the excluded evidence, McDonald's admissions to his acquaintances, was reliable: he made the statement to friends rather than police officers, he made three separate statements, and there was corroboration that McDonald owned the type of pistol used to kill the police officer. ${ }^{228}$ If Chambers is the benchmark, the right will rarely come into play. Moreover, the recognition of the due process right in civil cases is a quite recent phenomenon.

If the only available data were the American experience, the counterargument might be persuasive. However, this part of the article demonstrates that the experience of the judicial systems in many progressive, modern countries also points to the conclusion that privileges may be classified as conditional or qualified without crippling the various professions recognizing a duty of confidentiality.

\section{A. Civil Law Jurisdictions}

Many civil law systems categorize certain privileges as qualified. By way of example, in Denmark a judge may order a doctor or advokat to disclose confidential information when the information is of vital importance to the outc ome of a case. ${ }^{229}$ Furthermore, although Swedish law generally treats a person's private notes as privileged, the judge may compel their production if their disclosure is "extraordinarily important" to the correct disposition of

226. See id. at 1168-70.

227. See Chambers v. Mississippi, 410 U.S. 284 (1973).

228. Id. at 287-88.

229. Stephen O’Malley \& Alexander Layton, European Civil Practice $§ 49.49$ (1989). 
the litigation. ${ }^{230}$ Likewise, in Germany a member of the clergy may reveal otherwise privileged information if the revelation would serve a higher moral duty. ${ }^{231}$ For that matter, the catchall professional privilege recognized in Germany yields when the disclosure could promote a more important social interest. ${ }^{232}$ German law has also created a privilege for banking information, but in cases of necessity that privilege can be surmounted. ${ }^{233}$

\section{B. Common Law Jurisdictions}

There is even a trend toward the qualification of privileges in the common law world where Dean Wigmore's paradigm has been most influential.

\section{England}

England not only gave birth to common law privilege doctrine; England has also been bastion of the absolutist tradition in privilege doctrine. Yet, in 1972, R. v. Barton ${ }^{234}$ announced that it was inconceivable "that our law would permit a[n English] solicitor . . to screen from a jury information which, if disclosed to the jury, would perhaps enable a man either to establish his innocence or to resist an allegation made by the Crown." 235

It is true that in 1996 in R. v. Derby Magistrates' Court, ex parte B, the House of Lords adopted the contrary view. ${ }^{236}$ However, that decision has been sharply criticized by numerous commentators, ${ }^{237}$ and there have been calls for

230. Ruth Bader Ginsburg \& Ander s Bruzelius, Civil Procedure in Sweden 294 n. 458 (Hans Smit ed., 1965) (discussing RB 38:2(3) and 1943 NJA II, at 499).

231. A. Baumbach et Al., Zivilprozessordnung 1021 (43d rev. ed. 1985).

232. Id. at 1026 .

233. Peter Q. Noack, Comment, West German Bank Secrecy: A Barrier to SEC Insider-Trading Investigations, 20 U.C. DAVIS L. REV. 609, 621-22 (1987).

234. R. v. Burton, 2 All E.R. 1192 (Crown Ct. 1972).

235. See Colin Tapper, Cross and Tapper on Evidence 492 (8th ed. 1995).

236. R. v. Derby Magistrates' Court, ex parte B, 1 A.C. 487 (H.L. 1996). See Caryl Ben Basat \& Julian D. Nihill, Corporate Counsel, 31 InT'L LAw. 248, 250 (1997) ("The House of Lords recently confirmed the absolute nature of the legal professional privilege in R. v. Derby Magistrates' Court, ex parte $B$ and another appeal, 1 App. Cas. 487 (1996).... The House of Lords held that the privilege cannot be overridden even if the consequence is to deprive a court of evidence relevant to a person's innocence or guilt on a murder charge.").

237. I.H. Dennis, The Law of Evidence 327-30 (1999); Steve Uglow, Evidence: Text and MAterials 207 (1997) ("To hold that the court is never justified in undertaking a balancing exercise to compare the public interest in the lawyer/client privilege with the public interest in, for example, the liberty of an individual, seems unnecessarily wide and an approach that may well be regretted in hindsight. ... $[\mathrm{I}]$ tseems bizarre to state that legal professional privilege must in all circumstances outweigh the injury that 
Parliament to overrule the decision and declare that even purportedly absolute privileges must yield in extreme cases. ${ }^{238}$

Ultimately, though, it may prove unnecessary for Parliament to intervene. Even before Derby Magistrates' Court, there was English authority that the legal professional privilege (roughly corresponding to American attorneyclient privilege) can yield in a child custody proceeding when the privileged information is materially relevant to a critical issue in the proceeding. ${ }^{239}$ According to these authorities, the privilege should no longer be treated as absolute and may be overridden ad hoc when the material in question is highly "relevant to the determination of the case ...." decision postdating Derby Magistrates' Court, ${ }^{242}$ a "somewhat differently constituted House of Lords" reaffirmed that the legal professional privilege is not absolute in child care proceedings. ${ }^{243}$ Thus, there is reason to believe that the absolutist approach of Derby Magistrates ' Court will be short-lived. ${ }^{244}$

\section{Australia}

A shift away from absolutism is under way in Australia. As in England, there is authority that the paramount interests of a child can surmount the legal professional privilege. In one case, a mother allegedly hid her child in violation of a court order. ${ }^{245}$ The court ordered the mother's attorney to

would occur if an innocent person received a lengthy prison sentence."); Gavin Murphy, The Innocence at Stake Test and Legal Professional Privilege: A Logical Progression for the Law. . . But Not in England, [2001] CRIM. L. REv. 728, 730 (contrasting the approach taken by the House of Lords with the approach of the Canadian Supreme Court, the author asserts that the Lords' "inflexibility is out of step with the right to a fair trial ...."); A.A.S. Zuckerman, Note, Legal Professional Privilege-The Cost of Absolutism, 112 L.Q. Rev. 535, 536-39 (1996) (arguing that the Lords "place[d] legal professional privilege on [an] exalted and unassailable pedestal"; in the author's view "[s]urely a discretionary jurisdiction offers a better solution;" he expresses the hope that "the absolutist approach to legal professional privilege" will "be shortlived").

238. DENNIS, supra note 237 , at $327-30$

239. Re A (A Minor) (Disclosure of Privileged Material), [1994] 1 F.C.R. 225. See AdRiane Keane, The Modern Law of Evidence 582 (5th ed. 2000) (citing Oxfordshire County Council v. M, 2 All E.R. 269 (C.A. 1994)).

240. Re A (A Minor) (Disclosure of Privileged Information), [1994] 1 F.C.R. 225.

241. Re L (A Minor), All E.R. 78 (H.L. 1996). See Basat \& Nihill, supra note 236, at 251 ("In the case of In re L, the House of Lords held that litigation privilege cannot be relied upon in "nonadversarial proceedings' under the Children's Act 1989.”).

242. Richard May, Criminal Evidence 324 (4th ed. 1999).

243. Zuckerman, supra note 237, at 537.

244. Id. at 539 .

245. R. v. Bell, Ex parte Lees (1980) 146 C.L.R. 141. See M.I. Aronson ET AL., Litigation: Evidence and Procedure 191 (1982); 1 Aust. Law Reform Comm'n, Interim Report No. 26: 
disclose the child's whereabouts even though the attorney's knowledge of the whereabouts was based on confidential communications from the mother. ${ }^{246}$ Furthermore, although the state of the law with respect to an accused's ability to surmount the legal professional privilege might be in flux in England, in Australia, it is well-settled that an accused may do so. Early Australian case law $^{247}$ followed the view of the Barton decision ${ }^{248}$ that the privilege ought to yield when the privileged information will establish the accused's innocence. ${ }^{249}$ Then, as in England, the High Court did an about face in a 1995 decision, Carter v. Managing Partner, Northmore Hale Davy \& Leake. ${ }^{250}$ Carter held that legal professional privilege is absolute. ${ }^{251}$ However, it is an understatement to say that this absolutist approach was "short-lived" in Australia. ${ }^{252}$ Like Derby Magistrates' Court, Carter was subjected to harsh criticism. $^{253}$ In 1995, the very same year Carter was decided, a provision enacted in the Australian Evidence Act overturned Carter. ${ }^{254}$ By the terms of that provision, even an otherwise proper claim of legal professional privilege cannot prevent a defendant from adducing evidence relevant to showing his or her innocence. ${ }^{255}$

Evidence 53 (1985); 2 Aust. LAw Reform Comm'N, Interim Report No. 26: Evidence 276-77 (1985) (arguing the child's interests are paramount); Jenny McEwan, Evidence and the Adversarial Process-The Modern LAW 167 n.7 (2d ed. 1998) (“'litigation privilege' (attaching to third party reports commissioned by a solicitor on behalf of a client) does not apply in [child] care proceedings"); P. K. Waight \& C. R. Williams, Cases and Materials on Evidence 225 ( $2 \mathrm{~d}$ ed. 1985) ("It has been held that a solicitor is required to give to the court any information (including his client's address) which will enable the court to discover the whereabouts of a ward of the court whose residence is being concealed from the court, and that such information may not be the subject of a claim of professional privilege ...."); Peter Short, Legal Professional Privilege, 19 QueEns L. Soc. J. 125 (1989).

246. Bell, 146 C.L.R. at 141. Cf. Blau v. United States, 340 U.S. 332 (1951) (one spouse's knowledge of the other spouse's whereabouts was based on confidential communications from the other spouse).

247. Baker v. Campbell (1983) 153 C.L.R. 52, 68.

248. R. v. Barton, 2 All E.R. 1192 (Crown Ct. 1972).

249. Andrew Ligertwood, Australian Evidence $§ 5.32$, at 225 (2d ed. 1993) (stating that the trial judge may find that "in the circumstances" of the specific case, "the grounds for legal professional privilege" are "outweighed by policy reasons in favour of disclosure"); MCNICOL, supra note 108, at 103.

250. Carter v. Managing Partner, Northmore Hale Davy \& Leake (1995) 183 C.L.R. 121.

251. Ligertwood, supra note 249, at 285; TAPPER, supra note 235, at 459.

252. Zuckerman, supra note 237, at 536-39.

253. TAPPER, supra note 235, at 459.

254. DENNIS, supra note 237, at 330.

255. Stephen Ogders, Uniform Evidence Law 212-13 (2d ed. 1997) (stating, however, there is a statutory exception for fact situations in which the legal professional privilege is held by a co-accused the defendant is being jointly tried with). 


\section{Canada}

If anything, Canadian jurisprudence has moved farther than Australian law toward embracing a conditional or qualified conception of privileges. Even without the benefit of legislation, Canadian law is committed to the position that in an extreme case, an accused may override the legal professional privilege. ${ }^{256}$ The Canadian Supreme Court has expressly repudiated the approach taken by the House of Lords in Derby Magistrates' Court. ${ }^{257}$

Nor in Canada is the legal professional doctrine the only privilege categorized as qualified. During the 1970's, the Canadian Law Reform Commission considered legislation extending the same approach to all professional privileges. The commission drafted an evidence code, including the following provision:

A person who has consulted a person exercising a profession for the purpose of obtaining professional services, or who has been rendered such services by a professional person, has a privilege against disclosure of any confidential communication reasonably made in the course of the relationship if, in the circumstances, the public interest in privacy outweighs the public interest in the administration of justice. ${ }^{258}$

The statutory provision would have authorized trial judges to utilize a case-specific balancing test to determine whether to uphold a privilege claim. One study reasoned that although legitimate interests underpin evidentiary privileges, there can be competing "considerations of even higher value."259

256. Ronald Joseph Delisle, Evidence: Principles and Problems 646 (4th ed. 1996) (explaining that in R. v. Dunbar, [1982] 68 C.C.C.(2d) 13, 42 (Ont. C.A.), originally two defendants stood trial; one, Bray, was acquitted; in the second trial of the remaining defendant, "Bray's communications to his solicitor though initially privileged would be admissible as admission, would assist the co-accused, and could not injure Bray"); Paul Matthe ws \& Hodge M. Malek, Disclosure § 9.058, at 239 (2d ed. 2001) (explaining that in Canada, the legal professional privilege yields when the privileged information would tend to establish the accused's innocence); see David M. Paciocco, Charter Principles and Proof in Criminal CASEs 209-11 (1987) ("[t]he rule of R. v. Barton, because of the principle it reflects, should be applied with respect to all privileges"); Murphy, supra note 237 (discussing the Canadian Supreme Court's decision in the McClure case, [2001] S.R.C. 445, the author acknowledges that it will be a "rare" case in which the court surmounts an absolute privilege; however, the author approves of the McClure court's "total rejection of the House of Lords' refusal to override the privilege" in Derby Magistrates' Court).

257. See McClure, [2001] S.R.C., at 445.

258. The Law Reform Commission of Canada, Evidence Code $\S 41$ (Report: Evidence, Ottawa, Information Service, 1975). See also Shuman, Part III, supra note 123, at 399-401 (noting that some Canadian provinces do not recognize a psychotherapist privilege at all).

259. Shuman, Part III, supra note 123, at 417. 
Possibly based upon this reasoning, the commission's draft purported to create only a conditional or qualified privilege. The draft was designed to grant the trial judge more flexibility in accommodating the conflicting interests. ${ }^{260}$ In assessing the probative needs of the party seeking to introduce the evidence, under the draft, the judge could consider such factors as the importance of the issue the evidence relates to, the relevance of the evidence to that issue, and the availability of alternative, unprivileged information. ${ }^{261}$

Although that legislation was not enacted, since that proposal, in several decisions the Canadian courts have adopted the same approach as the legislative proposal. ${ }^{262}$ The courts have recognized several so-called "case by case" privileges ${ }^{263}$ - for instance, patient-psychiatrist $\mathrm{t}^{264}$ and journalistsource. ${ }^{265}$ Unlike the more traditional "class" or categorical privileges such as legal professional privilege, "case by case" privileges can be overcome ad hoc by a showing of compelling need for the privileged information. ${ }^{266}$ In evaluating the extent of the need, the Canadian courts consider a set of factors including the probative value of the privileged information. ${ }^{267}$

\section{Ireland}

Finally, although there is relatively little privilege case law in Ireland, there are indications that Ireland may follow suit and move toward the treatment of more privileges as conditional or qualified. It has long been established that in the case of claims of public interest immunity (the

260. Id. at 418 .

261. $I d$.

262. Bruce P. Archibald, The Uncertain "Revolution" in the Canadian Law of Evidentiary Privileges: What Principles Take Us Where?, in 2 New Trends in Criminal Investigation and EVIDENCE 11 (2000).

263. DelisLe, supra note 256, at 703 (citing R. v. Gruenke [1991] 3 S.C.R. 263 conferring privilege protection on communications with a pastor, the author distinguishes between case by case privileges and blanket, prima facie, or class privileges; when the court enforces the former type of privilege, the court does so on an ad hoc basis); Alan W. Mewett, Witnesses 15-46-49 (1991) (discussing Gruenke, as well as reviewing Slavutych v. Baker, [1976] 1 S.C.R. 254 involving a tenure assessment and M. (E.) v. Martinsen, [1993] 81 B.C.L.R.(2d) 184 involving counselling records for alcoholism and drug dependency); John Arnold Epp, Recognition of Religious Advisor Privilege in Canada's Supreme Court, 56 Mod. L. Rev. 233, 234, 237 (1992); Kinports, supra note 39, at 82 n.22.

264. M. (A.) v. Ryan [1997] 1 S.C.R. 157.

265. Coates v. The Citizen, [1986] 72 N.S.R.(2d) 116 (T.D.). See also Canadian Broad. Corp. v. Lessard, [1991] 3 S.C.R. 421. (2002).

266. 2 Edward J. Imwinkelried, The New Wigmore: Evidentiary Privileges § 12.2.3, at 1375

267. Archibald, supra note 262 , at 27-28. 
equivalent of the various American privileges for government information), Irish courts possess the power to surmount the claim ${ }^{268}$ based on the specific facts of the case, establishing an overriding need for the privileged information. ${ }^{269}$ In particular, an accused may defeat the informer privilege by showing that the informer possesses information vital to demonstrating his or her innocence. ${ }^{270}$

One of the leading Irish textwriters, Professor Caroline Fennell, reads the recent privilege decisions as reflecting "a ... desire on the part of the judiciary to extend ... judicial discretion to the private privilege area." ${ }^{271}$ She predicts a gradual "enhancement of the role of judicial discretion" in Irish privilege law. ${ }^{272}$ The Irish commentators concur that it is highly unlikely that the Irish courts will adopt the House of Lords' ruling in Derby Magistrates' Court that the legal professional privilege can never yield even when the privileged information is critical to establishing an accused's innocence. ${ }^{273}$ Moreover, in the case of the privilege for "without prejudice" or compromise ${ }^{274}$ communications, the Irish courts have stressed that " $[t]$ he rule, although firmly based on considerations of public policy, should not be applied in so inflexible a manner as to produce injustice."275

In all these jurisdictions, the various professions, including the legal and medical, appear to be every bit as robust and healthy as they are in the United States. Thus, like the empirical studies discussed in Part II of this article, the foreign experience undermines the assumption that the maintenance of these professions rigidly demands that any privileges for communications with members of these professions be treated as absolute.

268. Ruth Cannon \& Niall Neligan, Evidence 285 (2d ed. 2002).

269. Id. at 289 (citing Hughes v. Commissioner of An Garda Siochana, Unreported, High Court, Laffoy J., Jan. 20, 1998).

270. Id. at 271-72 (“In Ward v. Special Criminal Court [1998] 2 I.L.R. 493 O'Flaherty J. emphasized that informer privilege is not absolute and may be set aside where the disclosure of the identity of the informer might tend to show the innocence of an accused. This limitation on informer privilege has long been recognized."); Paul A. O'Connor, The Privilege of Non-Disclosure and Informers, 15 IRISH JuRIST $111,112-13,116$ (1980) (explaining that the judge "may, if the needs of justice so require, direct the name [of the informer] to be disclosed").

271. Caroline Fennell, The Law of Evidence in Ireland 212 (1992).

272. Id. at 215 .

273. Cannon \& Neligan, supra note 268, at 255, 265, 268-69. See also Fennell, supra note 271, at 205 ("legal professional privilege can be overridden when the evidence would enable the accused to establish his innocence").

274. FED. R. Evid. 408.

275. Ryan v. Connolly [2001] 2 I.L.R.M. 174; CANNON \& NELIGAN, supra note 268, at 271 ("the privilege may be departed from where the administration of justice requires this"). 


\section{Conclusion}

It would be comforting if we could indulge in Dean Wigmore's assumption that in privileged relationships such as attorney-client, the typical client would not consult or confide absent a privilege. On that assumption, we would have a virtually ideal situation. We could simultaneously protect sensitive social relationships without, on net, depriving the judicial system of relevant evidence needed to avoid miscarriages of justice. However, as Voltaire reminded us, we do not live in the "best of all possible worlds." ${ }^{276}$ The available empirical data undercuts the assumption that the average layperson is as obsessed by a fear of subsequent judicially compelled disclosure as Wigmore supposed. If that assumption is false, the recognition of privileges does not come cost free. Quite to the contrary, it comes at the price of miscarriages of justice; in many, if not most cases, the wooden application of an absolute privilege will suppress probative evidence that would have come into existence even absent the privilege.

Of course, there are cases in which Wigmore's theory is valid. Consider, for example, the facts in Jaffee. ${ }^{277}$ That case was a civil rights action arising from the police shooting of a civilian. ${ }^{278}$ The suit named as defendants both the police officer who shot the civilian and the municipality which employed the officer. ${ }^{279}$ The female police officer was so traumatized by the incident that she sought counseling. ${ }^{280}$ She had fifty counseling sessions. ${ }^{281}$ Although the record is unclear, at least some of those sessions might have occurred after the suit was filed or threatened. In addition, as a police officer, she probably had some familiarity with the law of evidence, perhaps including privilege doctrine. Or consider the facts in Swidler \& Berlin. ${ }^{282}$ The client in that case was Deputy White House Counsel Vincent Foster. ${ }^{283}$ Foster became so concerned about the Independent Counsel's investigation into the so-called "Travelgate" scandal that he retained private counsel, James Hamilton of the Swidler \& Berlin firm. ${ }^{284}$ During their consultation, Foster allegedly asked

276. Francois M. A. Voltaire, Candide ch. 6 (Daniel Gordon ed. \& trans., 1999) (1759).

277. Jaffee v. Redmond, 518 U.S. 1 (1996).

278. Id. at 4-5.

279. Id.

280. Id. at 3-4.

281. Id. at 5 .

282. Swidler \& Berlin v. United States, 524 U.S. 399 (1998).

283. Id. at 401

284. On May 13, 1993, the White House terminated seven Travel Office employees and replaced them with a Little Rock, Arkansas travel agency that had assisted the 1992 Clinton campaign. Paul A. 
Hamilton whether their consultation was confidential. ${ }^{285}$ When the record contains such facts, it is plausible to find that the patient or client would not have made the revelation without the assurance of confidentiality furnished by the privilege. When the case-specific facts support that finding, there is no need for the courts to resort to Wigmore's suspect generalization.

Some proponents of Wigmore's theory will undoubtedly predict dire consequences if the courts were to abandon Wigmore's generalization and classify privileges as qualified. However, such predictions are unwarranted. Even aside from the foreign experience with qualified privileges, the American experience with the work product doctrine is instructive. Although the Supreme Court fashioned a work product doctrine in Hickman v. Taylor ${ }^{286}$ Hickman did not confer absolute protection on any work product material, even documents reflecting the attorney's subjective evaluation of the case. Absent a contrary statute or court rule, most courts recognize only conditional or qualified protection for work product. ${ }^{287}$ In a later decision, Upjohn, the Court expressly noted that even after the adoption of the Federal Rules of Civil Procedure provision codifying the work product protection, some federal courts had "declin[ed] to adopt an absolute rule" 288 for opinion work product reflecting the attorney's theories, conclusions, and impressions. Common sense suggests that more than any other group in the United States, attorneys engaged in trial preparation are conscious of the risk of compelled judicial disclosure of their confidential communications. If attorneys can practice their profession despite the limited nature of the work product protection, it

Gordon, Note, Life after Death: The Attorney-Client Privilege-Swidler \& Berlin v. United States, 118 S. Ct. 2081 (1998), 72 Temp. L. Rev. 493, 494-95 (1999). The General Accounting Office ("GAO") investigated the dismissal of the prior employees. Id. at 495 . The Independent Counsel inquired to determine whether specific White House officials had "made false statements, committed perjury, obstructed justice, or committed other crimes" in the course of the GAO investigation. Id. at 495-96.

285. Id. at 523 ("As Hamilton remarked before the United States District Court for the District of Columbia, 'I am totally certain of one thing .... If I had not assured Vince Foster that our conversation was a privileged conversation, we would not have had that conversation, and there would be no notes that are the subject of this situation today."').

286. Hickman v. Taylor, 329 U.S. 495 (1947).

287. See Steven W. Feldman, The Work Product Rule in Criminal Practice and Procedure, $50 \mathrm{U}$. Cin. L. Rev. 495 (1981). In Hickman, the Court stopped short of announcing absolute protection even for work product material reflecting the attorney's theorizing or strategizing.

288. Upjohn v. United States, 449 U.S. 383, 401 (1981) ("We do not decide the issue at this time."). See also John Soumilas, Comment, Compilations: Truth, Privacy, and the Work Product Doctrine, 73 Temp. L. Rev. 227, 228, 236, 240, 242 (2000) (explaining that Rule 26(b)(3) now states that courts "shall protect against disclosure" of material revealing the "mental impressions, conclusions, opinions, or legal theories of an attorney"; yet, "[a] minority of jurisdictions ... such as the Second Circuit, have held that opinion work product is entitled to near absolute, but not categorical protection"). 
seems specious to argue that the law must recognize absolute communications privileges. In the past, the courts have not brushed aside qualified work product claims as a matter of course. ${ }^{289}$ The courts administering the doctrine have acted responsibly and paid attention to case-specific facts signaling a need for confidentiality. There is no reason to believe that the courts will run rough shod over claims of qualified privilege.

In the final analysis, the courts represent a justice system. Wigmore himself was committed to that proposition, but in his own mind he satisfactorily resolved the tension between that proposition and the protection of privileged relationships. His behavioral assumption conveniently enabled him to conclude that on balance, the recognition of privileges did not cause miscarriages of justice. However, as we have seen, that assumption is an overgeneralization. In many cases, the evidence suppressed by the privilege is evidence that would exist absent the privilege; and the suppression of highly relevant evidence can lead directly to unjust outcomes. The classification of privileges as absolute may enhance the certainty in the law of privileges, but that certainty has "been bought at the price of justice."

289. Soumilas, supra note 288 , at 228, 236, 240, 242.

290. Ho, supra note 1, at 30. 